\title{
Evaluation of Land Degradation and Socio-Environmental Issues: A Case Study of Semi Arid Watershed in Western Rajasthan
}

\author{
Sayema Jamal', Akram Javed', Yousuf Khanday² \\ ${ }^{1}$ Department of Geology, Aligarh Muslim University, Aligarh, India \\ ${ }^{2}$ Geological Survey of India, Jammu and Kashmir, India \\ Email: Sayema.alig@gmail.com
}

Received 18 April 2016; accepted 24 July 2016; published 27 July 2016

Copyright (C) 2016 by authors and Scientific Research Publishing Inc.

This work is licensed under the Creative Commons Attribution International License (CC BY). http://creativecommons.org/licenses/by/4.0/

c) (7) Open Access

\section{Abstract}

The present work attempts to assess the land cover changes at watershed level and status of land degradation in Mithri Watershed lying in the semi-arid tracts of Western Rajasthan, using time series climate data and remote sensing data and GIS techniques. The study also has a strong field component in the form of village wise surveys to record observations on climatic changes, agriculture, socio-economic condition of the community, water availability etc. Integration of remote sensing technique along with climate data analysis and household surveys, Group discussion and Participatory rural appraisal (PRA) was conducted to record land use/land cover changes and its impact on socio-economic condition of the people. Degradation mapping of the area reveals that area is affected by forest degradation, scrub erosion and salinization. Anthropogenic factors like fuel wood and timber extraction, livestock grazing etc. are also responsible for forest degradation. People have shifted from cash crops such as cotton to maize, barley and cereal during the last two decades.

\section{Keywords}

Land Degradation, Salinity, Remote Sensing, Land Use/Land Cover, Household Survey

\section{Introduction}

Land degradation is one of the most serious global environmental issues which threaten world food security, resulting in adverse impact on agronomic productivity. Land degradation has a broad range of definitions that essentially describe circumstances of reduced biological productivity of the land [1] [2].

Land degradation primarily relates to reduction in soil quality and quantity as an input to the production of 
agricultural crops. But there are also off-site effects, such as loss of watershed function [3]. In the context of productivity, land degradation results from a mismatch between land quality and land use [4]. Principal processes of land degradation include erosion by water and wind, chemical degradation (comprising acidification, salinization, fertility depletion, and decrease in cation retention capacity), physical degradation (comprising crusting, compaction, hard-setting etc.) and biological degradation (reduction in total and biomass carbon, and decline in land bio-diversity). In semi-arid regions, land-cover modifications, i.e. subtle changes that affect the character of the land cover without changing its overall classification, are common [5].

In conjunction with socio-economic surveys and censuses, as well as other biophysical information gathering techniques, remote sensing provides a better understanding of land use/cover dynamics and the factors that drive them [6]-[12]. Aggregated to the village-level, household data offer an additional perspective to the remotely sensed land-cover dynamics. The village profiles provide a crosscheck on the dynamics observed by remote sensing, and can be related to remotely sensed landscape variables [13] [14]. Individual household data allow for a better understanding of the land-use practices of each village, as most land-use decisions are made by individuals and households. This can lead to assessments or scenarios of sustainability of land use and vulnerability (or resilience) of communities, based on models of human-environment interactions.

Time series remote sensing data coupled with household data aggregated at the village level allowed an examination of structural changes related to economic variables which were otherwise difficult to examine using cross-sectional analysis, whether it was household, village or spatial.

Several studies combined socioeconomic household survey data and remote sensing data to better understand processes of land-use change [15]-[18]. Socio-ecological analysis of desertification in the Mu-Us Sandy Land in China was carried out by comparing desertification images and GIS-based thematic data and examining socioeconomic factors through interviews with local people [19]. Attempt was made to assess vulnerability to desertification at village level in the Southern Region of Malawi (South Africa) and analysed main anthropic factors and trends of agro-system degradation [20]. Based on questionnaire surveys, it was analyzed the effective parameters on participation of farmers in plans to combat desertification in Taraznahid of Markazi State, Iran [21]. Characterization, quantification and localization of areas at risk of desertification by comparative analysis of land degradation at municipality level in Brazil were done, in the municipalities of Araripina in the State of Pernambuco, Crato and Barbalha, State of Ceará and Marcolândia State of Piauí [22].

\section{Case Study}

It is estimated that about $32 \%$ of India's total land area is affected by land degradation and $25 \%$ of the geographical area is affected by desertification. About $69 \%$ of the country's land is drylands and degradation of this land has severe implications for the livelihood and food security of millions. Total area under land degradation is 105.48 mha. Area-wise Rajasthan, J\&K, Gujarat and Maharashtra have high proportions of land undergoing degradation. 81.45 mha land area of the country is undergoing the process of desertification.

The present study focuses on land degradation in a Mithri watershed, of Pali district in western Rajasthan representing semi-arid climate regime. The study integrates the climate data, land use/land cover change, anthropogenic causes and socio-economic indicators as tools to assess the extent of land degradation. The study envisages assessing social and economic status of the local people vis-a-vis climate change. Satellite data analysis of 1998 and 2010 clearly demonstrates the LU/LC changes, which have taken place as a result of climatic changes and anthropogenic activities.

\section{Study Site: Mithri Watershed, Pali District (Western Rajasthan)}

The study area has been chosen keeping in view the scarcity of natural resource in terms of water biomass, and degradation of vegetation cover in response to climate change which has eventually affected the productivity of land. The area has been experiencing decline in rainfall and increased frequency of droughts that has adversely affected rain fed agriculture production in most areas and poses a threat to the survival and livelihood of the rural population. About $75 \%$ people are involved in agricultural activities, are worst affected, socio-economically land degradation.

Mithri watershed lies in south eastern part of Pali district located between $73^{\circ} 16^{\prime} 02^{\prime \prime}$ and $73^{\circ} 28^{\prime} 05^{\prime \prime}$ E longitude 
and $26^{\circ} 13^{\prime} 29^{\prime \prime}$ and $26^{\circ} 58^{\prime} 48^{\prime \prime} \mathrm{N}$ latitude and covers an area of about $313 \mathrm{~km}^{2}$ (Figure 1). Digital Elevation Model (DEM) derived from ASTER (Advanced Spaceborne Thermal Emission and Reflection Radiometer) data reveals that higher elevations ranging from $(280-1100 \mathrm{~m})$ are encountered in the South-East part of watershed represented by Hills and Ridges.

Slope varies from $0^{\circ}$ to $47^{\circ}$. Mithri River is ephemeral in nature and flows from south east to northwest direction. Northern part of the Watershed is represented by Alluvial plain and aeolian sands whereas southern part comprises hills and ridges. Forest covers almost $40 \%$ of the watershed, and remaining $60 \%$ non-forest area is under various land use/land cover categories. The watershed has agricultural land as the dominant land use and people largely depend on rainfed agriculture for their livelihood.

\section{Data Sources \& Methodology}

Survey of India (SOI) topographic map 45 G/8 corresponding to, Pali district on 1:50,000 scale, was used for demarcation of watershed boundary taking slope, elevation and drainage flow directions as the basic inputs. Base map was prepared using relevant information on villages/town; elevation, contour lines, drainage network, major road and rail network were also extracted from the toposheets.

Standard Geocoded False Colour Composites (FCCs) of Indian Remote Sensing satellite (IRS) 1A LISS II, (Path: Row: 31 - 51) of 8th April, 1998 having a spatial resolution of 23.5 meter; (IRS-P6) LISS III (Path-Row: 93 - 54) of 7th May 2010 having spatial resolution of 23.5 meter on 1:50,000 scale was procured from National Remote Sensing Centre (NRSC), Hyderabad for thematic mapping. Meteorological data of monthly average maximum and minimum temperatures and annual average rainfall for 1969-2008 period for Pali district were obtained from India Meteorological Department (IMD), Pune.

The secondary information/data were collected and utilized wherever required for subsisting the current

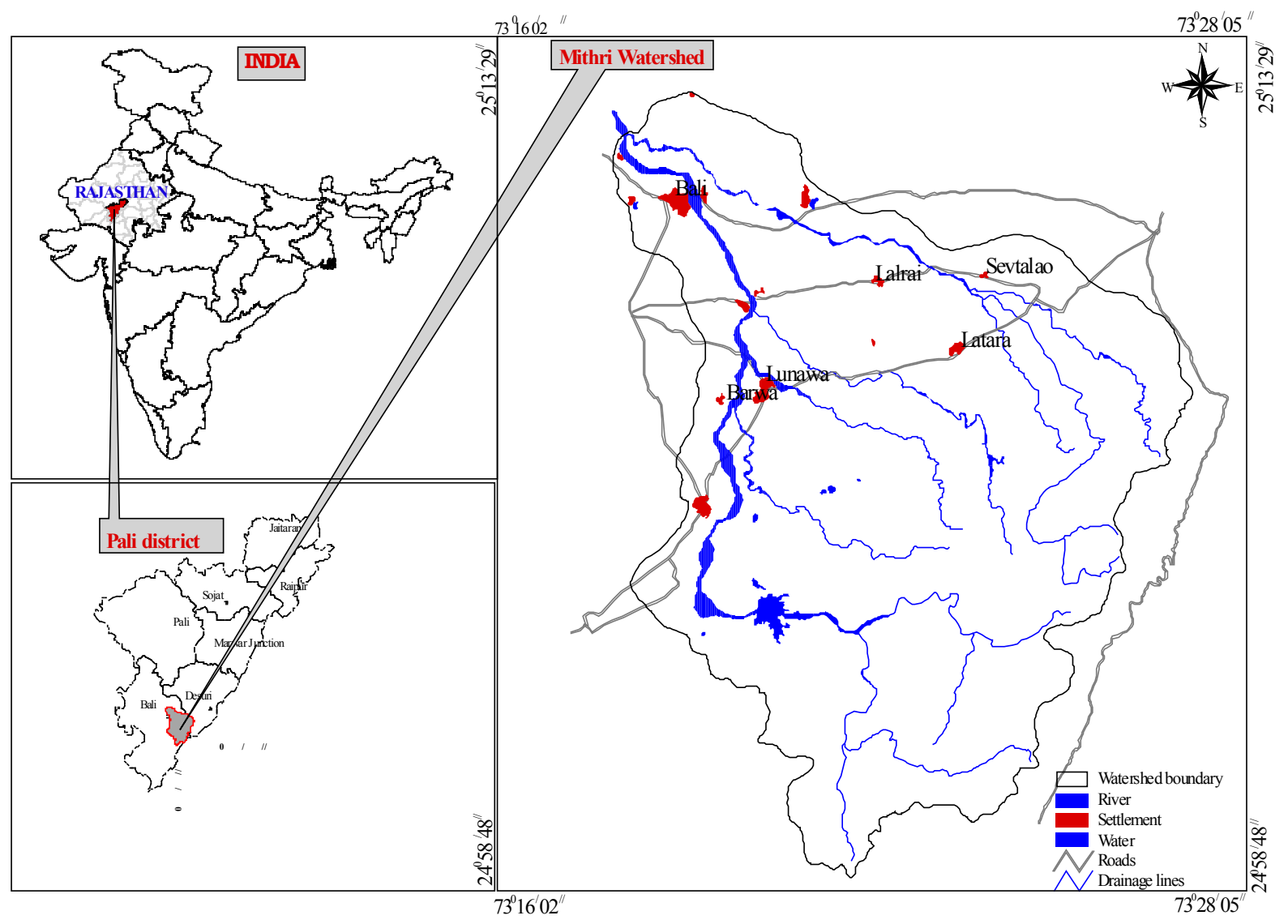

Figure1. Location Map of the study area. 
study, which includes Published research papers, technical reports, special volumes and memoirs of Geological Society of India, and information from other government and non-government sources were consulted for the present study.

Satellite data were visually interpreted using the photographic elements such as tone, texture, size, shape, pattern, association etc. for delineating various land use/land cover categories. Pre-field interpretation was verified during ground truthing verification and field inputs were incorporated wherever required. Land use/land cover maps were imported in ArcView GIS software for digitization, editing and spatial analysis, area computation and output. Change detection in land cover for the period 1998-2010 for Mithri was computed both, in square $\mathrm{km}$ as well as in percentage.

Structured questionnaire based household surveys at village level were conducted in eight villages of the Mithri watershed to assess various parameters of land degradation at landscape level. Information were recorded on variety of aspects related to socio-economic status, drinking water and fuel wood supply, crops grown and their output, source of irrigation, change in ground water level, shifts in crops, signs of land degradation and measures to control soil/water erosion and overall deterioration in natural resources. Apart from household surveys, Group discussion and Participatory rural appraisal (PRA) techniques were also adopted at village level to record the people's perceptions and their experiences in terms of changing climate, depletion of resources etc.

\section{Results and Discussion}

\section{Climate data analysis}

Pali district falls in semi-arid to arid climatic regime representing extremes, hot during summers and very cold during winter.

\subsection{Temperature}

The monthly temperature data for the period (1969-2008), were computed using "average growth rate formula" in R Software. It was divided into three seasons viz, winter (November, December, January \& February), summer (March, April, May \& October) and monsoon (June, July, August \& September). The results computed for annual average maximum and minimum temperature show an increasing trend for average maximum temperatures and decreasing trend for average minimum temperatures. Maximum day time temperature in summer has increased by $0.04^{\circ} \mathrm{C}$, winter and monsoon has decreased $0.38^{\circ} \mathrm{C}$ and 0.08 respectively. The minimum night temperature has shown a decline for summer and monsoon seasons by 0.28 and 0.39 respectively, and an increase for winter season by $0.42^{\circ} \mathrm{C}$.

\subsection{Rainfall}

Average annual rainfall of Pali district is $495.8 \mathrm{~mm}$, where average numbers of rainy days are only 22 in a year. Rainfall data analysis for the period (1969-2008), reveals that the area received maximum rainfall of $1955 \mathrm{~mm}$ in 1973 and minimum rainfall of $0 \mathrm{~mm}$ in 2000. Rainfall data shows a declining trend from $596 \mathrm{~mm}$ in 1969 to $455 \mathrm{~mm}$ in 2008 with total decline of $141 \mathrm{~mm}$ with a standard deviation of 338.34\% for 1969-2008 (Figure 2). Steep plunge in rainfall graph was in the years 1969, 1974, 1987, 2002 and 2008 points towards the years of severe droughts in the study area. Years of moderate drought were 1971, 1972, 1980, 1984, 1985, 1986, 1989, 1991, 1993, 1998, 2000 and 2004, whereas mild drought years are 1976, 1982, 1983, 1995, 1999 and 2003.

\subsection{Land Use/Land Cover Analysis}

The following land use/land cover categories are cultivated land, uncultivated land, dense forest, open forest, open scrub, wasteland, stone quarry, dry river channel, water body and built-up land. Forest has been classified into dense forest (greater than $40 \%$ canopy cover) and open forest (10\% - 40\% canopy cover). Change in the a real extent of various land use/land cover categories is discussed under each land use/land cover category. Area statistics of land-cover categories have been calculated for the year 1998 and 2010 at watershed level and (Figure 3, Table 1) and at village level (Table 2).

\section{Cultivated land}

Cultivated land is identified by their characteristic red tone, regular shape of the agricultural fields, association with the water bodies, etc. The crop lands are found well distributed throughout the foot hill zones and plain 


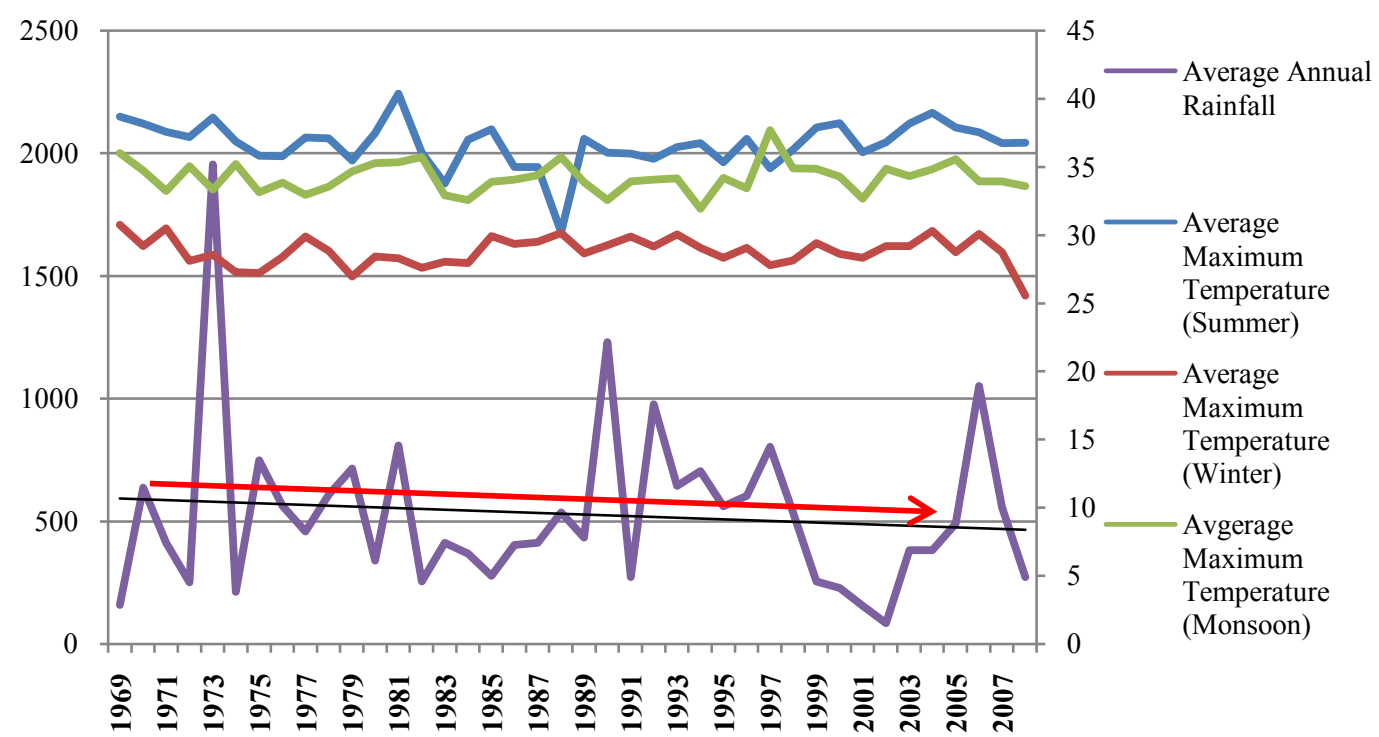

Figure 2. Trends in rainfall and temperature.

regions of the study area. Drought years led to decrease in cultivated land because of reduced net sown area. Cultivated land also suffered a setback because of lack of irrigation facilities since all the surface water dried up and water table dropped by 12 to $15 \mathrm{~m}$ in deep wells in the affected area. It covered an area of $37.31 \mathrm{~km}^{2}$ $(12.36 \%)$ in 1998 which reduced to $24.12 \mathrm{~km}^{2}(7.69 \%)$ in 2010 . Overall, loss of $13.19 \mathrm{~km}^{2}$ of cultivated land is observed. Decline in water table is another reason which has affected agriculture land leading to shrinkage in its area.

As far as village level analysis goes, all the nine villages which were surveyed have reported a reduction in area under cultivated land. The decrease is 68.90 ha in Sadra, 45.05 ha in Lalrai, 6.23 ha in Gurha kalyansingh14.04 ha in Dungli, 8.49 ha in Padarla, 23.19 ha in Mirgeshwar, 15.39 in Biliya, 4.89 in Karanwa.

Dense Forest

Dense forests have a characteristic dark red tone and dark green tone, smooth texture and are irregular in shape. In the study area, dense forest is present on the hill slopes in south-western part. Dense forest covers major part of the watershed in south west part. In 1998, it covered $90.09 \mathrm{~km}^{2}(28.75 \%)$. In a span of another 12 years, it has decreased to $72.94(23.87 \%)$ in 2010 . The decrease in area under open forest can be attributed to anthropogenic activities, livestock pressure and change in climate. The generally high temperatures and low precipitation has led to the depletion of vegetation cover. Open forest has progressively become thinner and less continuous in the last decade because of anthropogenic activities including population pressure.

Villagers generally uses fuel wood for cooking purpose, and unrestricted cutting of wood is also responsible for forest depletion and degradation. Increase in the frequency of droughts, occurring once in three years now, has affected the land use/land cover of the area in every aspect, quantitively as well as qualitatively.

Open forest

Open forest category can be identified from its dark red to medium red tone, irregular shape and medium texture. Open forests are found in western and northwestern areas and are associated with the areas nearer the dense forests. Open forest occupied $25.12 \mathrm{~km}^{2}(8.13 \%)$ in 1998 which increased up to $32.74 \mathrm{~km}^{2}(11.42 \%)$ in 2010 . An increase of area under open forest by about $4.14 \mathrm{~km}^{2}(2.58 \%)$ has been observed. This increase might be due to the loss in density (canopy cover) of dense forest which converted into open forest in due course of time because of decreased rainfall and anthropogenic activities.

\section{Uncultivated land}

Uncultivated land is identified by light grey and dark greenish tone within cropped area (red color), regular shape and medium texture. In the study area, such fallow lands are to be found well distributed in the central and south-eastern portions. During field survey it was noted that much of the land which was under cultivation before 6 - 7 years are lying barren because of decline in rainfall. Even if irrigation water is economically used, nearly $80 \%-90 \%$ of the arid area may not have access to water supply through irrigation. Area under uncultivated 


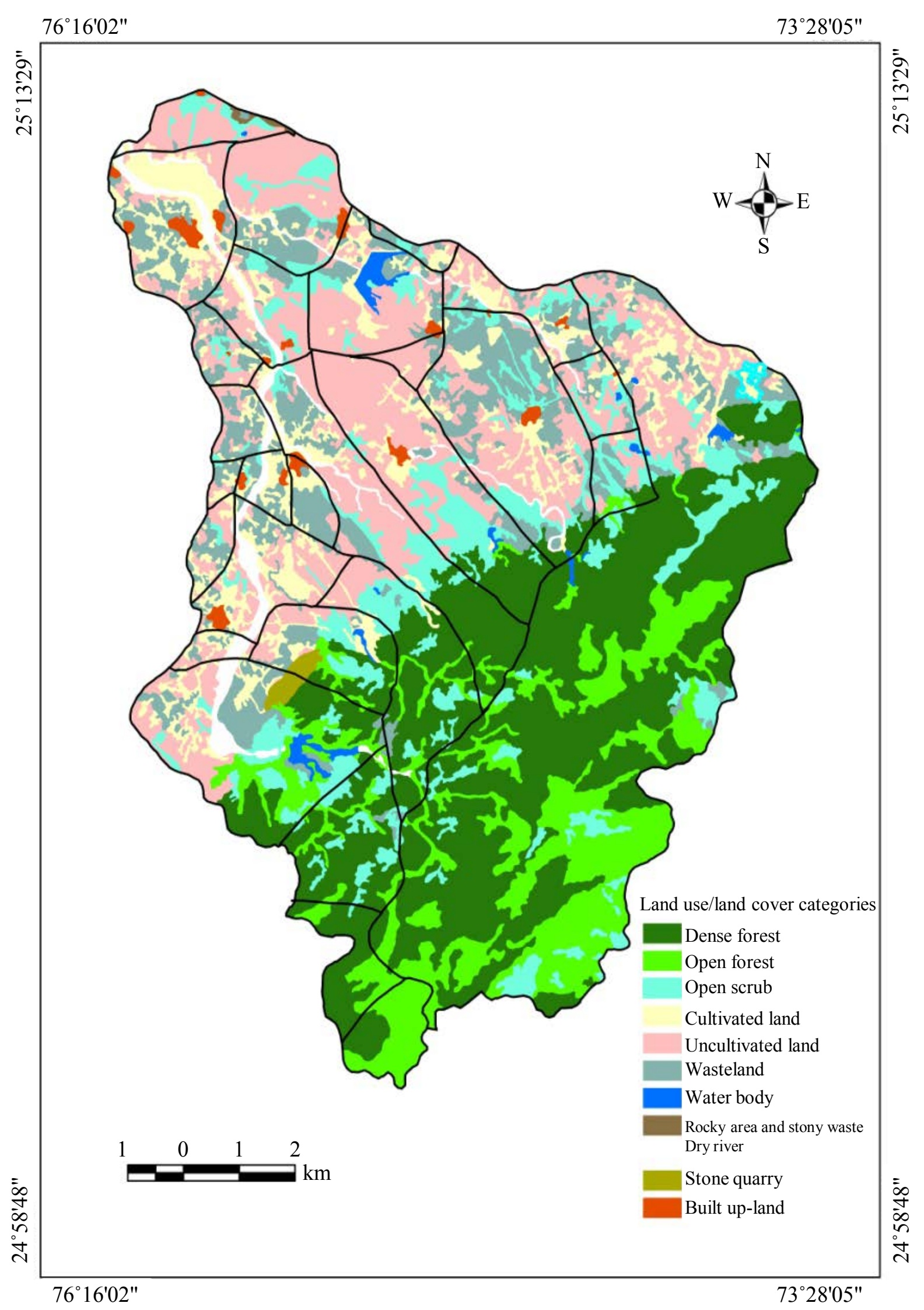




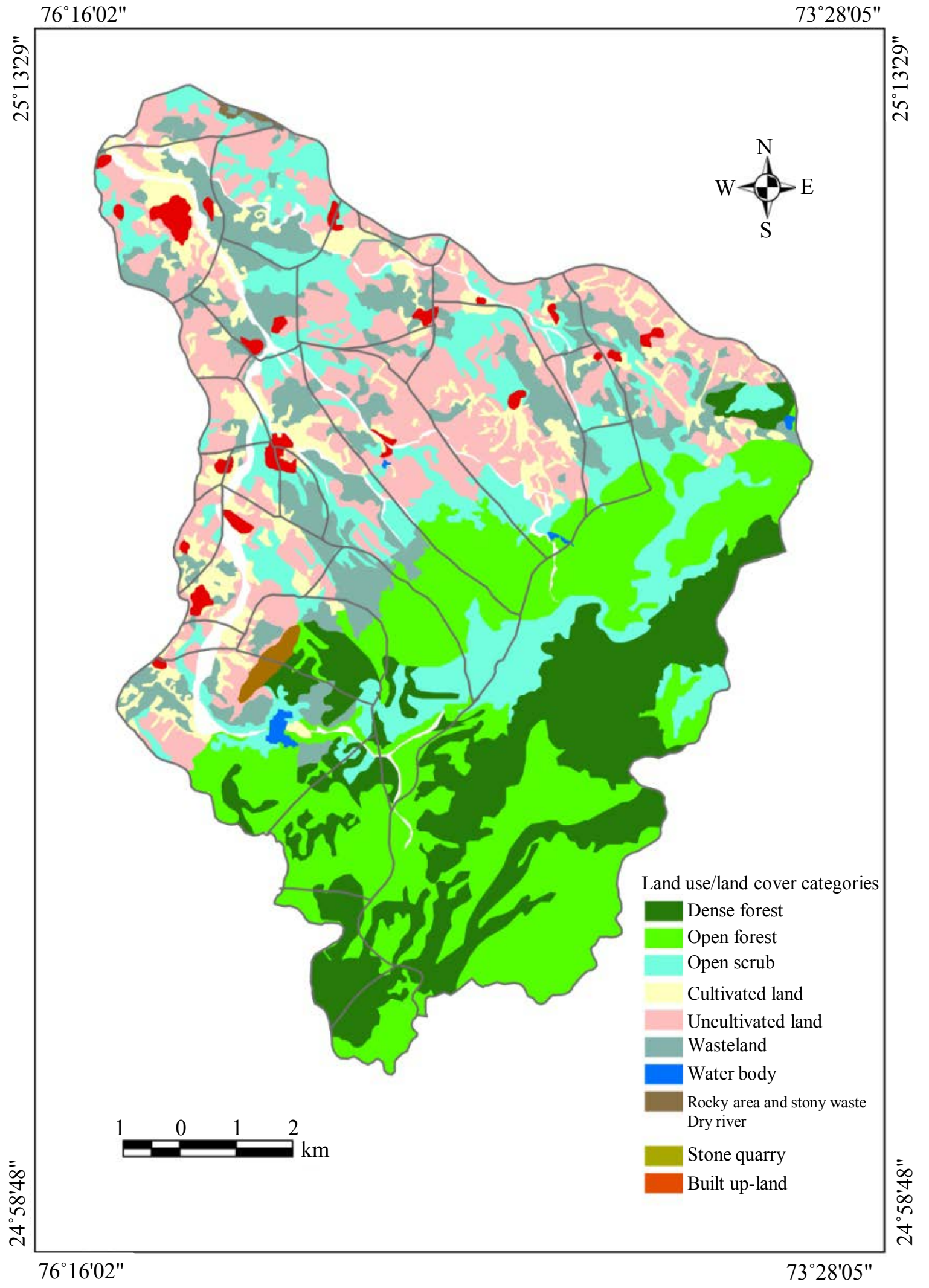

Figure 3. Land use/land cover of Mithri watershed of (a) 1998 and (b) 2010 with village boundary. 
Table 1. Land use/cover changes in the Mithri Watershed.

\begin{tabular}{ccccccc}
\hline LU/LC Classes & LU/LC $\mathbf{1 9 9 8}\left(\mathbf{K m}^{\mathbf{2}}\right)$ & Area in \% & LU/LC $\mathbf{~ 2 0 1 0}\left(\mathbf{K m}^{\mathbf{2}}\right)$ & Area in \% & \multicolumn{2}{c}{$\mathbf{1 9 9 8 - 2 0 1 0 ~ C h a n g e ~}$} \\
\hline Cultivated land & 37.31 & 12.36 & 24.12 & 7.69 & -13.19 & -4.67 \\
Uncultivated land & 38.36 & 13.97 & 49.23 & 16.56 & 10.87 & 2.59 \\
Dense forest & 90.09 & 28.97 & 72.94 & 23.87 & -17.15 & -5.1 \\
Open forest & 25.12 & 8.13 & 32.74 & 11.42 & 7.62 & 3.29 \\
Open scrub & 34.04 & 10.91 & 38.18 & 13.49 & 4.14 & 2.58 \\
Wasteland & 58.78 & 18.11 & 71.75 & 23.16 & 12.97 & 5.05 \\
Dry river channel & 7.42 & 2.38 & 8.1 & 2.58 & 0.68 & 0.2 \\
Water body & 2.5 & 0.95 & 0.7 & 0.22 & -1.8 & -0.73 \\
Built up land & 2.67 & 0.85 & 4.34 & 1.38 & 1.67 & 0.53 \\
Barren/Rocky area & 0.3 & 0.09 & 0.3 & 0.09 & 0 & 0 \\
Stone quarry & 1.38 & 0.49 & 1.42 & 0.52 & 0.04 & 0.03 \\
Total & 313.34 & 100 & 313.34 & 100 &
\end{tabular}

Table 2. Land use/land cover change statistics at village level in Mithri watershed.

\begin{tabular}{|c|c|c|c|c|c|c|c|c|c|c|}
\hline Villages & $\mathbf{L U} / \mathbf{L C}$ & CL & UCL & WL & OF & OS & $\begin{array}{l}\text { Dry } \\
\text { River }\end{array}$ & WB & $\begin{array}{l}\text { Built-up } \\
\text { land }\end{array}$ & $\begin{array}{l}\text { Total } \\
\text { Area }\end{array}$ \\
\hline \multirow{3}{*}{ Sadra } & 1998 & 156.32 & 858.14 & 123.65 & 281.97 & 312.59 & 23.54 & 11.01 & 9.71 & 1776.00 \\
\hline & 2010 & 87.42 & 727.41 & 305.81 & 228.00 & 361.14 & 38.41 & 3.25 & 24.56 & 1776.00 \\
\hline & $\begin{array}{c}\text { Net } \\
\text { Change }\end{array}$ & 68.90 & 130.73 & -182.16 & $\mathbf{5 3 . 9 7}$ & -48.55 & -14.87 & 7.76 & -14.85 & \\
\hline \multirow{3}{*}{ Lalrai } & 1998 & 128.61 & 494.65 & 158.65 & 31.54 & 97.53 & 14.83 & 91.95 & 14.77 & 1030.00 \\
\hline & 2010 & 83.56 & 450.00 & 315.00 & & 135.47 & 22.15 & & 25.82 & 1030.00 \\
\hline & $\begin{array}{c}\text { Net } \\
\text { Change }\end{array}$ & 45.05 & 44.65 & -156.35 & 31.54 & -37.94 & -7.32 & & -11.05 & \\
\hline \multirow{3}{*}{$\begin{array}{c}\text { Gurha } \\
\text { Kayansingh }\end{array}$} & 1998 & 12.000 & 107.64 & 28.000 & & & & & 3.59 & 151.23 \\
\hline & 2010 & 5.770 & 95.87 & 38.820 & & 5.84 & & & 5.09 & 151.23 \\
\hline & $\begin{array}{c}\text { Net } \\
\text { Change }\end{array}$ & 6.23 & 11.77 & -10.82 & & -5.84 & & & -1.50 & \\
\hline \multirow{3}{*}{ Dungli } & 1998 & 28.04 & 54.29 & 7.22 & & 12.18 & & & & 101.73 \\
\hline & 2010 & 14.00 & 66.60 & 9.00 & & 11.50 & & & & 101.73 \\
\hline & $\begin{array}{c}\text { Net } \\
\text { Change }\end{array}$ & 14.04 & -12.31 & -1.78 & & 0.68 & & & & \\
\hline \multirow{3}{*}{ Padarla } & 1998 & 75.16 & 85.36 & 78.92 & & 12.75 & 10.73 & & 4.00 & 266.41 \\
\hline & 2010 & 66.67 & 112.12 & 34.00 & & 23.27 & 21.32 & & 9.03 & 266.41 \\
\hline & $\begin{array}{c}\text { Net } \\
\text { Change }\end{array}$ & 8.49 & -26.76 & 44.92 & & -10.52 & -10.59 & & -5.03 & \\
\hline \multirow{3}{*}{ Mirgeshwar } & 1998 & 96.31 & 58.88 & 15.09 & & 8.70 & 28.00 & & 16.50 & 223.48 \\
\hline & 2010 & 72.38 & 48.64 & 49.00 & & & 33.40 & & 20.05 & 223.48 \\
\hline & $\begin{array}{c}\text { Net } \\
\text { Change }\end{array}$ & 23.93 & 10.24 & -33.91 & & 8.70 & -5.40 & & -3.55 & \\
\hline \multirow{3}{*}{ Biliya } & 1998 & 38.58 & 137.74 & 72.56 & & 76.53 & 7.90 & 3.79 & 2.13 & 338.27 \\
\hline & 2010 & 23.19 & 111.52 & 115.87 & & 72.32 & 10.29 & & 5.16 & 338.27 \\
\hline & $\begin{array}{c}\text { Net } \\
\text { Change }\end{array}$ & 15.39 & 26.22 & -43.31 & & 7.21 & -2.39 & & -3.03 & \\
\hline \multirow{3}{*}{ Karanwa } & 1998 & 25.11 & 117.69 & 42.00 & & 23.32 & 8.17 & & 8.17 & 226.14 \\
\hline & 2010 & 20.22 & 107.00 & 46.69 & & 32.37 & 3.91 & & 16.18 & 226.14 \\
\hline & $\begin{array}{c}\text { Net } \\
\text { Change }\end{array}$ & 4.89 & 10.69 & -4.69 & & -9.05 & 4.26 & & -8.01 & \\
\hline
\end{tabular}

Note: area in hectares. 
land in 1998 was $38.36 \mathrm{~km}^{2}(13.97 \%)$ which increased to $49.23 \mathrm{~km}^{2}(16.56 \%)$ in 2010 . Villages which show increase in uncultivated land include Sadra (130.73 ha), Lalrai (44.64 ha), Gurha Kalyansingh (11.77 ha), Mirgeshwar (23.93 ha), Biliya (26.22 ha) and Karanwa (10.69 ha).

\section{Wasteland}

Wasteland occupied an area of about $58.78 \mathrm{~km}^{2}(18.11 \%)$ in 1998 which increased to $71.75 \mathrm{~km}^{2}(23.16)$ in 2010. Prolonged droughts have induced severe decrease in vegetation cover and caused changes in the composition of the herbage layer as reflected by the increase in Angrezi babul. Depletion of Ground water level, and decline in rainfall triggered the conversion of cultivated land into uncultivated land leading to wasteland.

Among the surveyed villages wasteland has increased by 182.16 ha in Sadra, 156.35 ha in Lalrai, 10.82 ha Gurha kalyansigh, 1.78 ha in Dungli, 43.31 ha in Biliya, 33.91 ha in Mirgeshwar, 4.69 ha in Karanwa.

\section{Open Scrub}

Open scrub is the characteristic land cover present in arid and semi-arid areas. Thin veneer of soil cover supports scrubs and grass or devoid of vegetation where surface erosion is dominant. These lands are subjected to degradation or erosion and consist mainly of thorny bushes. Such areas were identified from their yellowish tone and their association with uplands, and their irregular shapes. Open scrub has increased from $34.04 \mathrm{~km}^{2}$ to 38.18 $\mathrm{km}^{2}(3.41 \%)$ from 1998 to 2010 . This increase in area under open scrub points towards land degradation occurring in the area as more of area has converted into unproductive land.

Open scrub has increased by 48.55 ha in Sadra, 37.94 ha in Lalrai, 5.84 ha in Gurha kalyansingh, 10.52 ha in Padarla, 66.90 ha in Mirgeshwar, 9.05 ha in Karanwa.

\section{Water bodies and River channel}

Recurring droughts adversely affected the surface water resources. As the water resource in the region is dependent on the scanty and erratic rainfall, the duration of availability of water in water bodies gets drastically reduced in drought years. Mithri River has remained dry for the past 10 - 11 years. Dry river channel area increased from $7.42 \mathrm{~km}^{2}(2.36 \%)$ to $8.10 \mathrm{~km}^{2}(2.5 \%)$ from 1998 to 2010 period. Surface water body area also decreased to $0.70 \mathrm{~km}^{2}(0.22 \%)$ because of drying up of a reservoir and other smaller surface water bodies.

The water features appear black in tone in the satellite imagery and dry river is white in tone. Area of dry River increased by 14.87 ha in Sadra, 10.59 ha in Padarla, 5.40 ha in Mirgeshwar and 2.39 ha in Biliya. Surface water body area decreased in 2010 because of drying up of check dam in the northern part of the watershed and other surface water bodies. Water body in Sadra decreased by 7.76 ha and the kot dam which comes under Lalrai got completely dry with a loss in of 91.95 ha surface water body in Lalrai village and 3.79 ha in Biliya village.

\section{Other land cover/land use}

Built up area has increased from $2.67 \mathrm{~km}^{2}(0.85)$ to $4.34 \mathrm{~km}^{2}(1.38 \%)$, primarily due to growth in Bali town. Built-up land increased by 14.85 ha in Sadra, 11.05 ha in Lalrai, 1.50 ha in Gurha Kalyansingh, 5.03 ha in Padarala, 3.55 ha in Mirgeshwar, 3.03 ha in Biliya, 8.01 ha in Karanwa, indicating more demand for residential land due to growth in population.

\section{Village Level Household Survey}

Aggregated to the village-level, household data offer an additional perspective to the remotely sensed land-cover dynamics. The village profiles provide a crosscheck on the dynamics observed by remote sensing, and can be related to remotely sensed landscape variables [13] [23]. Individual household data allow for a better understanding of the land-use practices each village, as most land-use decisions are made by individuals and households. Only when the physical (land use/land cover change) study and the social (socio-economic survey), are analysed together, a more complete picture of the environmental change can be Land use at village level is thought to be the most integrated information on how people recognize, utilize, manage and govern land resources, and the most important basis of their livelihood systems [24]. The interaction between land cover/use change and livelihoods is an important theme for understanding the issue of rural poverty in human-environment relationships [25].

To assess the impacts of land degradation on agriculture a household level survey was carried out in 8 villages of the watreshed, using structured questionnaires, besides group discussion and PRA were also conducted. The eight villages selected are Biliya, Ghura Kalyansingh, Padrala, Sadra, Lalrai, Doongli, Mirgeshwar, and Karanwa. 


\subsection{Socio-Economic Condition}

Results of survey revealed the deteriorating condition of land/soil which has severely affected the rainfed agriculture. The prime reason of land degradation is the persistent decrease in rainfall as elaborated by the villagers and elderly farmers. The survey shows $95 \%$ of people are engaged in agriculture and related activities and casual labour for their livelihood. Remaining $5 \%$ has government service and took up some private jobs like driving, cooking etc. People from villages like Biliya (80\%), Sadra (94\%), Karanwa (64\%), Lalrai (38\%) depends heavily on livestock for livelihood, sell dairy products in nearby market and rear sheep's wool. The Average annual income of the people in the surveyed villages ranges from ₹ 35000 to little more than ₹ 45000 . 19\% of people have annual income less than ₹ 35000, 32\% have annual income of ₹ 35000 - ₹ 45000 and $49 \%$ falls in the income group more than ₹ 45000 (Table 3).

\subsection{Agriculture: Facts and Figures}

Most of the farmers are small and marginal who grow crops for self consumption. About $60 \%$ of the farmers possess agricultural lands that are rain fed. Many farmers though having large land holding size but due to limited quantity of water and poor yield in the tube wells they are only able to cultivate few hectares of their land, leaving large tracts of land at the mercy of nature.

Table 3. Socio-economic status of the villages surveyed.

\begin{tabular}{|c|c|c|c|c|c|c|c|c|c|c|c|}
\hline \multirow{2}{*}{ Villages } & \multirow{2}{*}{$\begin{array}{l}\text { Total } \\
\text { area } \\
\text { (ha) }\end{array}$} & \multirow{2}{*}{$\begin{array}{c}\text { Population } \\
\text { density } \\
\text { (persons/ha) }\end{array}$} & \multirow{2}{*}{$\begin{array}{l}\text { Avg no. } \\
\text { of } \\
\text { persons } \\
\text { in } \\
\text { household }\end{array}$} & \multicolumn{3}{|c|}{ Avg. annual income (\%) } & \multirow{2}{*}{$\begin{array}{l}\text { Avg. } \\
\text { land } \\
\text { holding } \\
\text { size (in } \\
\text { bighas) }\end{array}$} & \multirow{2}{*}{$\begin{array}{l}\text { Avg. } \\
\text { no. of } \\
\text { cattles }\end{array}$} & \multicolumn{2}{|c|}{$\begin{array}{c}\text { Distance } \\
\text { travelled }(\mathbf{k m})\end{array}$} & \multirow{2}{*}{ Major fuel } \\
\hline & & & & $\stackrel{\text { ₹ }}{<35000}$ & $\begin{array}{c}\text { ₹35000 - } \\
45000\end{array}$ & $\underset{45000}{₹>}$ & & & $\begin{array}{c}\text { Drinking } \\
\text { water }\end{array}$ & fw & \\
\hline Biliya & 227 & 2.54 & 7 & 20 & 40 & 40 & 5 & 10 & 2 & 2 & $\begin{array}{l}78 \% \text { fw only, } \\
22 \% \text { fw \& LPG } \\
\text { both }\end{array}$ \\
\hline $\begin{array}{c}\text { Gurha } \\
\text { Kalyansingh }\end{array}$ & 187 & 3.06 & 7 & 16 & 50 & 33 & 18 & 4 & 0.95 & 1.5 & $\begin{array}{l}97 \% \text { fw only, } \\
5 \% \text { fw \& LPG } \\
\text { both }\end{array}$ \\
\hline Karanwa & 1081 & 22.05 & 6 & 21.43 & 35.71 & 42.86 & 7.5 & 8 & 0.2 & 36 & $\begin{array}{l}95 \% \text { fw only, } \\
5 \% \text { fw \& LPG } \\
\text { both }\end{array}$ \\
\hline Biliya & 227 & 2.54 & 7 & 20 & 40 & 40 & 5 & 10 & 2 & 2 & $\begin{array}{l}78 \% \text { fw only, } \\
22 \% \text { fw \& LPG } \\
\text { both }\end{array}$ \\
\hline $\begin{array}{c}\text { Gurha } \\
\text { Kalyansingh }\end{array}$ & 187 & 3.06 & 7 & 16 & 50 & 33 & 18 & 4 & 0.95 & 1.5 & $\begin{array}{l}97 \% \text { fw only, } \\
5 \% \text { fw \& LPG } \\
\text { both }\end{array}$ \\
\hline Karanwa & 1081 & 22.05 & 6 & 21.43 & 35.71 & 42.86 & 7.5 & 8 & 0.2 & 36 & $\begin{array}{l}95 \% \text { fw only, } \\
5 \% \text { fw \& LPG } \\
\text { both }\end{array}$ \\
\hline Padarla & 980 & 2.68 & 6 & 27.27 & 18.18 & 54.55 & 12 & 10 & 0.7 & 3 & $\begin{array}{l}81 \% \text { fw only, } \\
19 \% \text { fw \& LPG } \\
\text { both }\end{array}$ \\
\hline Dungli & 424 & 3.54 & 6 & 12 & 32 & 56 & 8 & 5 & 0.5 & 1.5 & $\begin{array}{l}85 \% \text { fw only, } \\
15 \text { fw \& LPG }\end{array}$ \\
\hline Lalrai & 1195 & 1.53 & 6 & 23.80 & 38.10 & 38.10 & 20 & 11 & 0.46 & 2.5 & $\begin{array}{l}66 \% \text { fw only, } \\
44 \% \text { fw \& LPG } \\
\text { both }\end{array}$ \\
\hline Sadra & 2041 & 0.69 & 6 & 17.65 & 23.53 & 58.82 & 13 & 4 & 0.3 & 3 & $\begin{array}{l}97 \% \text { fw only, } \\
\% \text { fw \& LPG } \\
\text { both }\end{array}$ \\
\hline Mirgeshwar & 281 & 10.43 & 7 & 27.27 & 18.18 & 54 & 8 & 3 & 0.3 & 2.4 & $\begin{array}{c}73 \% \text { fw only, } \\
27 \text { fw and LPG } \\
\text { both }\end{array}$ \\
\hline
\end{tabular}

Note: area in hectares, fw-fuel wood, LPG-liquid petroleum gas. 
Common crops grown in the area comprise maize, green pea, sesame, sorghum bicolor, mustard seeds, black eyed pea and pearl millet which require less water. Wheat is grown where sufficient water is available for irrigation. Agriculture production in the villages has declined by $30 \%-40 \%$, during the last two decades due to frequently occurring drought, decreased rainfall and gradually falling water table. Farmers having 50 - 80 bighas of land are unable to produce good output due to unavailability of water for irrigation. The main sources of irrigation in the area are wells $(47 \%)$, tube wells $(47 \%)$ and tanks $(6 \%)$. It was reported that 20 years back water table was at 60 - 70 feet, now it has gone down to 170 feet; and in Biliya even up to 200 feet has been reported.

Survey found dozens of well have dried up, and people are unable to afford the cost of drilling the wells to greater depths. Only rich farmers have installed tube wells in their fields, and also reap the benefits of government subsidies. To arrest soil erosion, only $10 \%$ farmers practice bunding and contouring, rest $90 \%$ leave their land as such. Some farmers also told about the increase in level of sands in their fields. Besides, Desi babool (Acacia nilotica) there is widespread increase in Angrezi babool (Prospis Juliflora) and other cactus plant during the last two decades which is eating away the top layer of the soil. Problem of termite was reported from Sela village, where farmers complain that their produce is destroyed in the field if they leave it even for two days.

About $80 \%$ of farmers have reported decrease in fertility of soil in their fields because of low rainfall and no irrigation facilities. Other factors as reported include destruction of crops by Blue bull (Boselaphus tragocamelus) in Dungli and termites in Gurhakalyansingh.

\section{Participatory rural appraisal (PRA) and Group discussion:}

Participatory Rural appraisal is an effective tool to elicit people's perception about an issue. PRA and group discussion were conducted at several villages during the survey and it was observed that farmers having $70-80$ bighas of land are unable to produce good output due to non-availability of water. Earlier people used to sell their extra produce, now they have to buy some quantities of food grain to fulfil their family needs. Farmers have now switched to crops which require less water like maize, moong, jowar, and raida, in place of cotton and gram.

People report of substantially decreased and erratic rainfall, and increased temperature. Ponds, river lets and dams have all dried up. Very few of the farmers have ensured their crops. On an average agriculture yield has decreased by $40 \%$, but the people who could not avail the irrigation facility have reported decrease in yield of about less than half. $82 \%$ people hold responsible the decreasing rainfall for their reduced agriculture yields (Table 4). Other factors as reported include destruction of crops by Blue bull (Boselaphus tragocamelus) in Dungli and termites in Gurhakalyansingh.

Table 4. Decline in water table, change in crops yield and pattern.

\begin{tabular}{|c|c|c|c|c|c|}
\hline \multirow{2}{*}{ Village } & \multicolumn{2}{|c|}{ Depth to Water table (feet) } & \multirow{2}{*}{$\begin{array}{l}\text { Decrease in yield } \\
(\%)\end{array}$} & \multicolumn{2}{|c|}{ Crops grown } \\
\hline & Presently & 20 years back & & Presently & 20 Years back \\
\hline Biliya & $120^{\prime}-130 ’$ & $70^{\prime}-80^{\prime}$ & $37 \%$ & $\begin{array}{l}\text { Sesame seeds, Maize, Pearl millet, } \\
\text { Green gram, Wheat }\end{array}$ & $\begin{array}{l}\text { Gram, red chilli, Rajma, } \\
\text { cotton }\end{array}$ \\
\hline $\begin{array}{c}\text { Gurha } \\
\text { Kalyansigh }\end{array}$ & $170^{\prime}$ & 100 & $48 \%$ & $\begin{array}{l}\text { Sesame seeds, Maize, Pearl } \\
\text { millet, Green gram, Wheat }\end{array}$ & cotton, wheat \\
\hline Karanwa & $100^{\prime}$ & $50^{\prime}-60^{\prime}$ & $41 \%$ & $\begin{array}{c}\text { Sesame seeds, Green gram, Maize, } \\
\text { Wheat, Mustard }\end{array}$ & Cotton, wheat, gram \\
\hline Padarla & $160^{\prime}$ & $60^{\prime}-70^{\prime}$ & $31.25 \%$ & $\begin{array}{l}\text { Sesame seeds, Maize, Green gram, } \\
\text { Pearl millet, Wheat, Mustard }\end{array}$ & Cotton, wheat \\
\hline Dungli & $170^{\prime}$ & $100^{\prime}$ & $47.86 \%$ & $\begin{array}{l}\text { Sesame seeds, Maize, Green gram, } \\
\text { Pearl millet, Wheat, Mustard, rai }\end{array}$ & Tara mira, Cotton \\
\hline Lalrai & $100^{\prime}-150 ’$ & $600^{\prime}$ & $31 \%$ & $\begin{array}{l}\text { Sesame seeds, Maize, Green gram, } \\
\text { Pearl millet, Wheat, Mustard, rai }\end{array}$ & Cotton, gram \\
\hline Sadra & $120^{\prime}-150^{\prime}$ & $80^{\prime}-90^{\prime}$ & $41 \%$ & $\begin{array}{c}\text { Sesame seeds, Maize, Green gram, } \\
\text { Pearl millet, } \\
\text { Wheat, Mustard, rai }\end{array}$ & Cotton, methi \\
\hline Mirgeshwar & $100^{\prime}$ & $50^{\prime}-60^{\prime}$ & $36.25 \%$ & $\begin{array}{l}\text { Sesame seeds, Maize, Green gram, } \\
\text { Pearl millet, Wheat, Mustard, rai }\end{array}$ & Cotton, wheat, gram \\
\hline
\end{tabular}


S. Jamal et al.

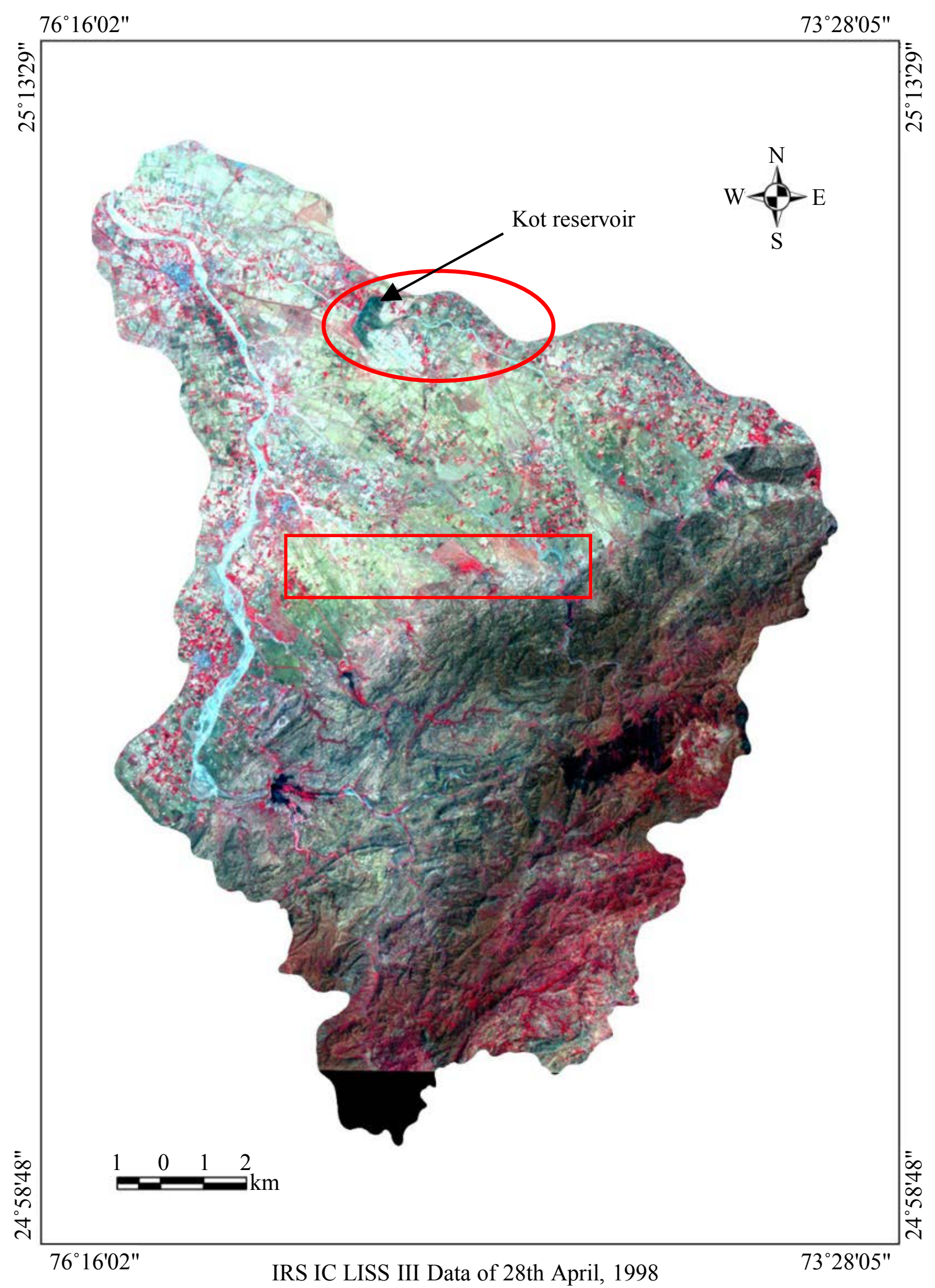




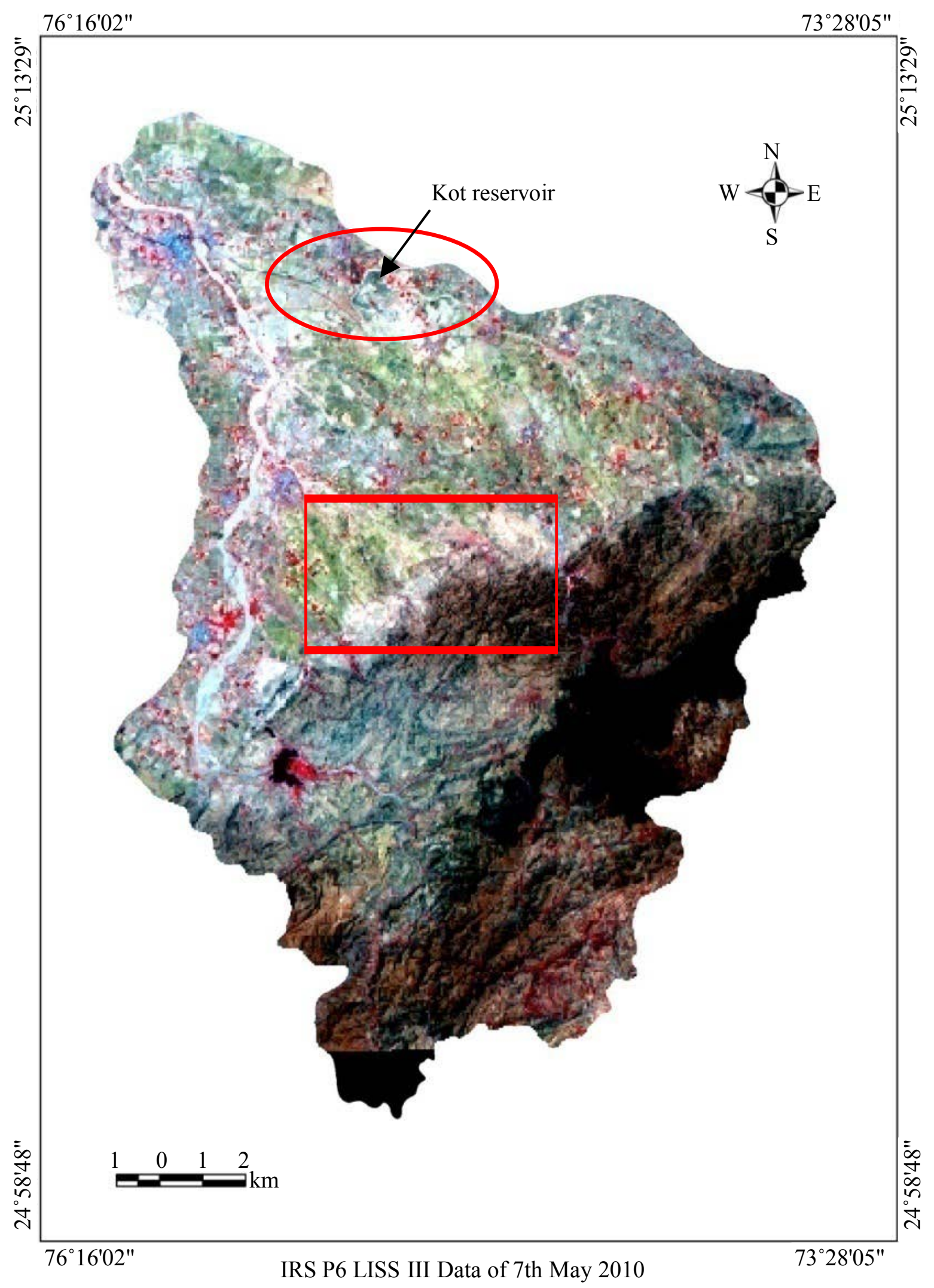

Figure 4. Satellite images. 
Table 5. Fall in depth to water table.

\begin{tabular}{ccc}
\hline OLDER ALLUVIUM & 1998 (below ground level) & 2010 (below ground level) \\
\hline Latada & 77.88 & 114.5 \\
Sewari & 66.43 & 136.64 \\
GRANITE & & 105.479 \\
Bali (P) & 93.3 & 118.77 \\
Boya & 70.54 & 98.92 \\
Kot & 64.14 & 123.03 \\
Mundara & 94.69 & 162.73 \\
Juna & 70.21 & 84.32 \\
Ranakpur & 30.51 & 62.01 \\
Sadri & 57.58 & 83.17 \\
Guda Chota & 29.92 & 98.43 \\
Falna & 76.67 & \\
\hline
\end{tabular}

Source: Ground water department, Pali.

The natural fluctuation of the water table in the Pali region reflects the seasonal distribution of the rainfall. Depth of water level ranges from 60 in plain areas to 120 feet in hilly region, because of recurrence of drought and decline in rainfall in the last two decades water level has gone down to $50-60$ feet. People reported that 1990 year was a year of good rainfall $(1231.6 \mathrm{~mm})$ in the last two decades, during which ground water table rose upto 50 feet. Agriculture production has been good during the 1990-1996 period. Drought of moderate intensity occurred in 1999, followed by severe drought in 2002 and 2008. The year 2009 and 2010 were years of good rainfall, which has led to rise in water table and good crop production.

\section{Soil degradation}

Surface reflectance of soil changes as a result of exposed lower horizon or deposition of alleviated material. There is a high correlation between soil reflectance and several properties such as mineralogy, organic matter content, moisture content, colour and soluble soil content [26]. The remote sensing data could be used efficiently in delineating areas affected by soil degradation.

Satellite Images of 1998 and 2010 show variations in spectral reflectance of various soil type and its degradation (Figure 4). Kot reservoir (encircled with red colour) in 1998 image appears dark because of availability of water; the same Kot reservoir is seen dried-up in 2010 image and has almost vanished. Land adjacent to Kot dam also appears white because of alkalization of soil. Repeated use of underground water at deeper levels having high PPM of fluoride and continual use of DAP, urea, pesticide, insecticide in view of increasing the productivity of land has actually led to increased alkalization of cultivated land to more than $\mathrm{pH}$ of more than 8.5. Pockets of land/soil having bright white tone can be seen scattered in northern part and to the right bank of the dried Mithri River.

Ground water depth and its quality play an important role in salinization/alkalization of soils in arid and semi-arid areas; hence watertable depth, its salt concentration and composition are considered key elements in the appraisal, monitoring and amelioration of the salt-affected lands [27].

In the arid and semi-arid regions, irrigation is necessary for agricultural production. Table $\mathbf{5}$ presents the increase in depth to water table in the villages falling in watershed, in 1998-2010 (Ground Water Department, Pali), showing average decrease of 41 feet.

Farmers are forced to extract water from deep wells with high salt content to irrigate their land. While excess water application may cause rising of water table, it can also cause increase of soil salinity. Because of erratic nature of rainfall farmers, have no alternative but to use low-quality water for irrigation, disregarding completely future consequences of likely soil salinity [28].

\section{Conclusions}

Land use/land cover analysis of study area clearly reflects light on the ongoing land degradation because of de- 
creased rainfall and anthropogenic activities. Major changes that have been recorded include degradation of dense forest, conversion of cultivated land to uncultivated land owing to decline in rainfall and depletion of ground water resources, and increase in wasteland. The land degradation has consequently affected the socioeconomic condition of the people in villages badly. People are forced to stop cultivation in their agricultural land because of increased cost of irrigation, switching off to other crops of low economic value, and have to pay heavily for fertilizers and pesticides because of increased pest attacks. Some of the farmers have to migrate to other states in search of other means of livelihood.

Such kind of studies gives a deeper insight of the problem faced by the people living in such conditions. And unless informed of the problems, how can these be resolved and brought to the attention of the government?

\section{Acknowledgements}

The financial support received from University Grants Commission (UGC), New Delhi under Major Research Project 33-49/2007 (SR) to the senior author is thankfully acknowledged. Thanks are also due to the Chairman, Department of Geology, A.M.U., Aligarh for providing necessary infrastructure facilities. Sincere thanks to Society for Sustainable development, Karauli, for assisting in household surveys in the study area. Thanks are also due to Dr. Yousuf Khanday, Dr. Subha Rais and Dr. Sana Iftekhar for their help in data generation and analysis.

\section{References}

[1] UNCCD (1994) United Nations Convention to Combat Desertification in Countries Experiencing Serious Drought and/or Desertification, Particularly in Africa. A/AC.241/27, Paris.

[2] Reynolds, J.F. and Stafford-Smith, M. (2002) Global Desertification: Do Humans Create Deserts? In: Stafford-Smith, M. and Reynolds, J.F., Eds., Do Humans Create Deserts? Dahlem University Press, Berlin, 1-22.

[3] Coxhead, I. and Oygard, R. (2008) Land Degradation. Copenhagen Consensus.

[4] Beinroth, F.H., Eswaran, H., Reich, P.F. and Van Den Berg, E. (1994) Land Related Stresses. In: Virmani, S.M., Katyal, J.C., Eswaran, H. and Abrol, I.P., Eds., Stressed Eco-Systems and Sustainable Agriculture, Oxford and IBH, New Delhi.

[5] Diouf, A. and Lambin, E.F. (2001) Monitoring Land-Cover Changes in Semi-arid Regions: Remote Sensing Data and Field Observations in the Ferlo, Senegal. Journal of Arid Environments, 48, 129-148. http://dx.doi.org/10.1006/jare.2000.0744

[6] Quattrochi, D.A. and Goodchild, M.F. (1997) Scale in Remote Sensing and GIS. Lewis Publishers, New York.

[7] Quiring, S.M. and Papakryiakou, T.N. (2003) An Evaluation of Agricultural Drought Indices for the Canadian Praires. Agricultural and Forest Meteorology, 118, 49-62.

[8] Liu, J.G. (2001) Integrating Ecology with Human Demography, Behaviour, and Socioeconomics: Needs and Approaches. Ecological Modeling, 140, 1-8. http://dx.doi.org/10.1016/S0304-3800(01)00265-4

[9] Veldkamp, A. and Lambin, E.F. (2001) Predicting Land Use Change. Agriculture, Ecosystems and Environment, 85, 16. http://dx.doi.org/10.1016/S0167-8809(01)00199-2

[10] Parker, D.C., Manson, S.M., Janssen, M.A., Hoffmann, M.J. and Deadman, P. (2003). Multi-Agent System Models for the Simulation of Land-Use and Land-Cover Change: A Review. Annals of the Association of American Geographers, 93, 314-337. http://dx.doi.org/10.1111/1467-8306.9302004

[11] Walsh, S.J. and Welsh, W.F. (2003) Approaches for Linking People, Place and Environment for Human Dimensions Research. Geocarto International, 18, 51-61. http://dx.doi.org/10.1080/10106040308542281

[12] Walsh, S.J., Entwisle, B., Rindfuss, R.R., Shao, Y., Weiss, D.J., McDaniel, P.M. and Pullen, R.E. (2003) Characterizing Land Use/Land Cover Change in Northeast Thailand and Analyzing the Causes and Consequences of Landscape Dynamics. Proceedings of 30th International Symposium on Remote Sensing of Environment, Honolulu, Hawaii.

[13] Walsh, S.J., Entwisle, B., Rindfuss, R.R. and Page, P.H. (2006) Spatial Simulation Modeling of Land Use/Land Cover Change Scenarios in Northeastern Thailand: A Cellular Automata Approach. Journal of Land Use Science, 1, 5-28. http://dx.doi.org/10.1080/17474230600604213

[14] Entwisle, B., Walsh, S.J., Rindfuss, R.R. and Chamratrithirong, A. (1998) Land-Use/Land-Cover and Population Dynamics, Nang Rong, Thailand. In: Liverman, D., Moran, E.F., Rindfuss, R.R., Geoghegan, J. and Stern, P.C., Eds., People and Pixels: Linking Remote Sensing and Social Science, National Academy Press, Washington DC, 121-144.

[15] Mertens, B. and Lambin, E.F. (2000) Land-Cover Change Trajectories in Southern Cameroon. Annals of the Association of the American Geographers, 90, 467-494. http://dx.doi.org/10.1111/0004-5608.00205 
[16] Guyer, J.I. and Lambin, E.F. (1993) Land-Use in an Urban Hinterland: Ethnography and Remote Sensing in the Study of African Intensification. American Anthropologist, 95, 839-859. http://dx.doi.org/10.1525/aa.1993.95.4.02a00040

[17] Behrens, C.A., Baksh, M.G. and Mothes, M. (1994) A Regional Analysis of Bari Land-Use Intensification and Its Impact on Landscape Heterogeneity. Human Ecology, 22, 279-316. http://dx.doi.org/10.1007/BF02168854

[18] Sussman, R.W., Sussman, L.K. and Green, G.M. (1994) Satellite Imagery, Human Ecology, Anthropology, and Deforestation in Madagascar. Human Ecology, 22, 333-354. http://dx.doi.org/10.1007/BF02168856

[19] Moran, E. and Brondizio, E. (1998) Land-Use Change after Deforestation in Amazonia. In: Liverman, D., Moran, E., Rindfuss, R. and Stern, P., Eds., People and Pixels, National Academy Press, Washington DC, 45-67.

[20] Kobayashi, T., Nakayama, S., Wang, L.M., Li, G.Q. and Yang, J. (2005) Socio-Ecological Analysis of Desertification in the Mu-Us Sandy Land with Satellite Remote Sensing. Landscape and Ecological Engineering, 1, 17-24. http://dx.doi.org/10.1007/s11355-005-0003-3

[21] Boschetto, R.G., Mohamed, R.M. and Arrigotti, J. (2010) Vulnerability to Desertification in a Sub-Saharan Region: A First Local Assessment in Five Villages of Southern Region of Malawi. Italian Journal of Agronomy/Rivista di Agronomia, 3, 91-101.

[22] Pirmoradi, A.H., Hosseini, S.M. and Hosseini, S.J.F. (2011) Effective Parameters on Farmers' Participation in Plans to Combat Desertification (PCDs). African Journal of Agricultural Research, 6, 5582-5590.

[23] Fernandes, M.F., Barbosa, M.P. and Neto, J.M.M. (2012) Analysis of Levels of Land Degradation Using Landsat-5, Municipalities of Araripina (PE) Crato and Barbalha (CE) and Marcolândia (PI), Brazil. Soil and Water Engineering, International Conference of Agricultural Engineering-CIGR-AgEng 2012: Agriculture and Engineering for a Healthier Life, Valencia, 8-12 July 2012.

[24] Mertens, B., Sunderlin, W.D., Ndoye, O. and Lambin, E.F. (2000) Impact of Macroeconomic Change on Deforestation in South Cameroon: Integration of Household Survey and Remotely-Sensed Data. World Development, 28, 983-999. http://dx.doi.org/10.1016/S0305-750X(00)00007-3

[25] Saphangthong, T. and Kono, Y. (2009) Continuity and Discontinuity in Land Use Changes: A Case Study in Northern Lao Villages. (Special Issue: Land Use Changes in the Uplands of Southeast Asia: Proximate and Distant Causes). Southeast Asian Studies, 47, 263-286.

[26] Ueda. G. (2011) Land Subdivision and Land Use Change in the Frontier Settlement Zone of Mount Meru, Tanzania. African Study Monographs, 42, 101-118.

[27] Chandio, F.A. Soomro, A.G., Memon, A.H. and Talpur, M.A. (2011) Influence of Watertable Depth on Soil Sodicity and Salinity. World Academy of Science, Engineering and Technology. International Journal of Environmental, Chemical, Ecological, Geological and Geophysical Engineering, 5, 416-420.

[28] Sadeh, A. and Ravina, I. (2000) Relationships between Yield and Irrigation with Low-Quality Water Đ a System Approach. Agricultural Systems, 64, 99-113. http://dx.doi.org/10.1016/S0308-521X(00)00016-0

\section{Submit or recommend next manuscript to SCIRP and we will provide best service for you:}

Accepting pre-submission inquiries through Email, Facebook, Linkedin, Twitter, etc

A wide selection of journals (inclusive of 9 subjects, more than 200 journals)

Providing a 24-hour high-quality service

User-friendly online submission system

Fair and swift peer-review system

Efficient typesetting and proofreading procedure

Display of the result of downloads and visits, as well as the number of cited articles

Maximum dissemination of your research work

Submit your manuscript at: http://papersubmission.scirp.org/ 